\title{
USING WEBSITES TO RECRUIT FRANCHISEE
}

\section{CANDIDATES}

\section{Begoña López-Fernández(a), Rozenn Perrigot (b)}

(a) Facultad de Economía y Empresa, University of Oviedo, Avda del Cristo, s/n, 33071 Oviedo, Spain

(b) Center in Franchising, Retail \& Service Chains, Graduate School of Management (IGR-IAE Rennes), CREM UMR CNRS 6211, University of Rennes 1, 11 rue Jean Macé - CS 70803, 1135708 Rennes Cedex 7, France

Please cite this article as: Begoña López-Fernández, Rozenn Perrigot, Using Websites to Recruit Franchisee Candidates, Journal of Interactive Marketing (2018), vol. 42, pp.80-94

https://doi.org/10.1016/j.intmar.2018.02.003

\section{HIGHLIGHTS}

- Franchisor websites often do not provide the most effective information needed for franchisee recruitment.

- Both functional and symbolic benefits are related to effective franchisee attraction.

- Certain categories of information targeting franchisee candidates and chain growth can have either positive or negative outcomes.

- Some categories of information meant to encourage franchisee attraction are superfluous and may be counterproductive in terms of overloading candidates' attention.

\section{Acknowledgments}

The authors acknowledge the French National Research Agency (FRANBLE - ANR-12BSH1-0011-01), the Spanish Ministry of Economy and Competitiveness (ECO2017-85704R), as well as the Center in Franchising, Retail \& Service Chains for their valuable support. 


\title{
USING WEBSITES TO RECRUIT FRANCHISEE CANDIDATES
}

\begin{abstract}
Unlike other interorganizational relationships, such as joint ventures, franchisors commonly display information on their websites with the objective of attracting franchisee entrepreneurs and having them sign standardized contracts. This paper analyses, for the first time, how franchise brands disclose both functional and symbolic benefits and their effect on franchise chain growth. Our empirical study, based on an in-depth analysis of 106 websites, suggests that both types of benefits are intertwined in advertising franchise opportunities. Information on financial requirements, contact facilities and recruiting processes are positively related to franchise chain growth, whereas information on business potential (financial expectations) is negatively related to growth. Moreover, information on continuous assistance is relevant for service-type franchisee candidates. Finally, our observations show that information available in all the categories is far from exhaustive and that influential information is frequently absent from franchisor websites.
\end{abstract}

\section{KEYWORDS}

Franchising, Internet, Online communication, Recruitment, Franchisee candidates, Franchise branding. 


\section{INTRODUCTION}

Business format franchising is defined as

"a contractual arrangement between two independent firms, whereby the franchisee pays the franchisor for the right to sell the franchisor's product and/or the right to use his trademark at a given place and for a certain period of time $[\ldots]$ [T] he relationship between franchisor and franchisee 'includes not only the product, service, and trademark, but the entire business format itself - a marketing strategy and plan, operating manuals and standards, quality control, and continuing two-way communication"” (Lafontaine 1992, p. 264).

Franchising is growing in most countries and in most industries. Even in experienced markets, as in the United States, franchising growth consistently outperforms that of the economy, accounting for a 3\% of the GDP (International Franchise Association 2016).

In order for franchise chains to grow, however, franchisors have to focus on two areas: the marketing of their final products, vis-à-vis the final customers, and the marketing of their business concepts, vis-⿳亠㐅冋-vis the franchisee candidates. In this study, our focus is on the marketing of franchisors' business concepts and, more specifically, on their communication with franchisee candidates. To attract franchisee candidates and make their chain grow, franchisors usually use a multi-channel strategy (Perrigot, Basset and Cliquet 2011) comprised of both offline communication tools (e.g., booths at franchise exhibitions, advertisements in specialized press, specialized recruiting agencies) and online communication tools (e.g., franchisor websites, specialized websites, social media).

In this context, recruitment of franchisee candidates through websites has become a widespread business-to-business practice that shapes franchise branding (Zachary et al. 2011). 
Even though Internet technologies in business have advanced from Web 1.0 to Web 3.0 (Garrigos-Simon, Lapiedra Alcamí and Barberá Ribera 2012) within the franchise sector, websites are used extensively as information portals ${ }^{1}$ (Web 1.0) for the purpose of recruitment (e.g., more than $83 \%$ of franchisors use them in the United States, Australia and France [Young, McIntyre and Paswan 2004; Rao and Frazer 2006; El Akremi et al. 2012]). As such, earlier studies regarding recruitment information displayed on franchise websites have been merely descriptive. In contrast, our study advances website recruiting research in franchising by testing its effectiveness in promoting chain growth. In doing so, we draw on the marketing and franchising literature with a focus on signaling and agency theories to examine (1) whether information displayed on franchisor websites plays a relevant role in the decisionmaking process of franchisee candidates; (2) how the contents contribute to franchise branding; and (3) which types of information are significantly related to chain growth.

From this perspective, we consider the categories of information provided on franchisor websites, classify them depending on the types of benefits they provide to the franchise brand and identify which categories of content are related to franchise chain growth, as growth is a major goal of franchisors (e.g., Combs, Ketchen and Short 2011; Norton 1988) and a proxy for profitability (Lafontaine 1993).

Our empirical study is based on an in-depth content analysis of 106 franchisor websites drawn from retail and service industries in France. This French context is relevant because of the dynamism of franchising in France in terms of the number of franchise chains $(1,900$ franchisors with 71,508 franchised stores generating $€ 55.10$ billion of total sales [French Franchise Federation 2017]) and chain growth $(+2.91 \%$ in $2015-2016$ [French Franchise Federation 2017]). In fact, $83.5 \%$ of franchising sales in the European Union are derived from

\footnotetext{
${ }^{1}$ We thank an anonymous reviewer for raising this point.
} 
$25 \%$ of the member states (Abell 2016), France being amongst the highest ranked contributors.

Building on these points, the study contributes to the literature in several ways. First, we enlarge the limited research available on Internet adoption and franchising expansion, thereby responding to the call for research on "the problems surrounding the adoption of new technologies [...] in franchised chains" (Lafontaine 2014, p 22) by focusing on what information may be relevant for recruiting new franchisees. Second, we build on the scarce literature available on franchisee recruitment (Watson et al. 2016; Zachary et al. 2011) by showing the kinds of information franchisors disclose on their websites. Third, our study contributes to a field of research, suggested by Ratchford (2015), on the drivers and effects of online advertising in interactive marketing and highlights the relevant categories in terms of franchise chain growth that would benefit franchisors. Fourth, as franchisees are entrepreneurs in a B2B relationship, we respond to Varadarajan and Yadav (2009) who report that research on communicating and interacting with businesses remains limited. Finally, our paper also has managerial implications in terms of franchisee candidate recruitment and franchise branding. Appropriate signaling of the right information may enhance efficiency when attracting franchisees and assigning resources to advertising (Michael 2009).

In Section 2, we review the existing literature on franchisor online communication used to attract franchisee candidates and formulate the research hypotheses. We describe the methodology in Section 3, while in Sections 4 and 5 we present and discuss the results of our empirical study. 


\section{LITERATURE REVIEW}

\subsection{Recruitment in franchising}

Recruitment raises particular issues within franchising, because it is typically targeted toward two types of candidates: franchisees and corporate employees. Prospective franchisees are the focus of our present research. Attracting prospective franchisees is particularly challenging because franchisees are entrepreneurs and/or investors who are assessing new business opportunities. Although they may share some of the same concerns as employees, their recruitment processes are more complex. For instance, unlike employees, franchisees commit their own capital in long term investments and receive residual claims from their outlets rather than a salary. One outcome is that this residual claimant status ensures dedication on the part of the franchisees, thus reducing agency costs relative to hiring employees. In fact, this advantage may explain the franchisor's choice of franchising as a governance form (Norton 1988; Lafontaine 1992; Sen 1998; Michael 2000b). Moreover, franchising may minimize adverse selection problems because franchisees, unlike certain employees, do not have the incentive to misrepresent themselves. As well, franchising has been perceived as a response to agency problems related to geographic dispersion of outlets (Norton 1988; Lafontaine 1992). Franchisees do not need the same close supervision as employees and are managed through persuasion. By saving agency costs and offsetting entrepreneurial capacity problems through high powered incentives (Norton 1988), franchising can be considered a growth strategy for chains (Combs, Ketchen and Short 2011; Dant and Berger 1996; Kaufmann and Dant 1996; Lafontaine 1992; Norton 1988; Sen 1998).

However, franchising growth can only come about after careful pre-screening of franchisee candidates by franchisors (Bradach 1997), because the costs involved in terminating a franchise contract are much higher than the costs of terminating an employment contract 
(Michael 2000a). In fact, the selection of appropriate franchisee candidates is considered one of the main operating challenges for franchisors (Jambulingan and Nevin 1999; Watson et al. 2016).

This paper addresses the research gap on e-recruitment and examines the content and implications of the information displayed on franchisor websites in terms of franchise branding and growth. Early studies report that franchisors commonly use this medium to recruit new franchisees (e.g., Cedrola and Memmo 2009; Dixon and Quinn 2004; Rao and Frazer 2006; Young, McIntyre and Paswan 2004) and that the primary goal of a franchisor's website is to promote the concept to franchisee candidates (Martin 1999). For instance, $83.5 \%$ of franchisors use their websites to attract franchisee candidates in the United States (Young, McIntyre and Paswan 2004), 86.1\% in Australia (Rao and Frazer 2006) and 85.61\% in France (El Akremi et al. 2012).

Franchisors often use a mix of online and offline means to inform and persuade candidates, as well as other forms of successive interaction (Stephens 2007; Michael 2009) like face-to-face meetings, for example. However, there are numerous advantages to recruitment by means of websites compared to other more traditional methods, such as setting up booths at franchise exhibitions or creating brochures that may serve as complements to or substitutes for website recruitment. First, websites provide easy access to a large number of franchisee candidates who can navigate the websites at will. Second, websites are an effective means of providing information and are relatively inexpensive to construct (Dixon and Quinn 2004). Third, in terms of cost reduction, past research on employee recruitment estimates that Internet recruitment amounts to a tenth of the cost of traditional methods and the timing of recruitment and selection can be reduced by $25 \%$ (Lievens and Harris 2003). Fourth, the Internet is a dynamic and consistent means of conveying information, because the company controls the 
message $^{2}$ (Lievens and Harris 2003). Fifth, via their websites, franchisors can recruit on their own. This option is preferable when franchisors believe that external recruiting companies do not have the knowledge or the incentive to attract the most suitable franchisee candidates (Weaven, Frazer, and Giddings 2010). Sixth, positive externalities exist for the way customers and potential employees for company-owned stores can be attracted. Seventh, the Internet also simplifies comparisons for franchisee candidates, which can lead to more informed decision-making.

However, recruitment of franchisee candidates through websites may also present some pitfalls. First, there is the need to filter a high number of applicants if there is over-attraction. In principle, the emphasis on recruitment via the Internet focuses on attracting candidates rather than selecting the best ones (Lievens and Harris 2003). In order to avoid this, franchisors can minimize the time and effort required in selecting candidates by designing their websites in a way to attract franchisee candidates with particular profiles. Second, there are some limitations associated with website communication because it is very often onedirectional, done at a distance and is a-synchronous, so there is no immediate interaction between franchisors and the franchisee candidates (Cable and Yu 2006). Third, the recruitment of franchisee candidates via websites may be inappropriate for certain franchisee candidate profiles, such as foreign candidates who are unfamiliar with the brand or single-unit franchisees that are already part of the chain and want to become multi-unit franchisees.

\footnotetext{
${ }^{2}$ However, a drawback of this one-sided control is that it may lead to ex-post conflict if the franchisor misrepresents information.
} 


\subsection{Value proposition of the franchise chain on franchisor websites}

\subsubsection{Value proposition}

Communication through websites is a tangible means of conveying a franchise chain's values and organizational identity, that is, the enduring perception of what makes an organization distinct (Albert and Whetten 1985; Zachary et al. 2011). It contains ex-ante voluntary information disclosure that may signal some of the franchisor's attributes. Zachary et al. (2011), in their study of franchisor websites, coined the concept "franchise branding" to describe "how franchisors position franchise opportunities to attract potential franchisees" in coherence with their organizational identity.

Effective communication of organizational identity may ultimately sell a business opportunity. The sales funnel framework, developed as a theory of communication, illustrates the cognitive phases that buyers follow when purchasing a product (Michaelson and Stacks 2011), such as franchise business opportunities announced in recruiting websites. In the case of franchising, these phases comprise an awareness of the concept and an interest in the benefits of the franchise opportunity. These lead to a desire and a purchase decision (or intent to purchase). In attracting franchise candidates through their websites, franchisors should take these phases into account by carefully shaping the contents of their websites to attract candidates who may become partners in a B2B relationship.

Although the use of recruiting websites by franchisors is ubiquitous, as discussed above, information provided on the Internet is only a first step in the decision-making process of franchisee candidates that will include long term investments of time, talent and capital. However, our contention is that this information may influence prospective investors by attracting their attention and interest. In fact, past research highlights that beliefs about 
organizational identity are developed very early on at a moment prior to the recruitment process and are hard to modify (Barber 1988; Cable and Yu 2006), so this preliminary contact with the brand may have an impact on prospective franchisees' choice. Even though there are many other variables that influence franchise growth, this information may have a significant impact on franchise branding and growth.

Hence, our hypothesis is the following:

H1: Display of information targeting franchisee candidates on franchisor websites has a positive relationship with franchise chain growth.

\subsubsection{Functional and symbolic benefits}

Franchisors voluntarily post on their websites some of the information included in the mandatory disclosure documents that they provide to franchisee candidates prior to signing a franchise contract with them. These legal obligations are aimed at facilitating franchisee candidates in making sound decisions about their investments as part of the pre-sale due diligence process and should be furnished in any tangible form that can be preserved and read. For example, in France, these data include the company's experience, the state and prospects for development of the relevant market, the size of the chain, the terms of the contract, the conditions for its renewal, its termination and its transfer and the scope of exclusive rights (French Code du Commerce Article L330-3). In the United States, certain states may require franchisors to provide a Franchise Disclosure document (FDD) that can include up to 23 items that contain information primarily pertaining to the franchisor and the performance of the franchise chain.

This information, common to the mandatory disclosure documents, in conjunction with other benefits mentioned on the website, contributes to create a brand image. Any brand image may 
be broken down into functional and symbolic benefits or dimensions (e.g., Aaker 1991; Padgett and Allen 1997; Rampl and Kenning 2014) according to the underlying drivers to which they are connected. Whereas functional benefits are product-related and correspond to fairly basic, practical attributes, symbolic benefits are expressive, not product-related and tend to enhance self or social esteem, as shown in figure 1. Therefore, product-related information, as included in mandatory documents, can be considered functional.

\section{Insert figure 1 about here}

This functional content, similar to mandatory pre-contractual information, is useful for the rational decision-making we would expect to find in B2B sectors (Lilien et al. 2010). When a prospective franchisee assesses a new business opportunity, profitability comes to mind (Sadeh and Kacker 2017). However, there are other topics that franchisors may cover on their websites, including parts of the mandatory disclosure documents, and not all of these may be conducive to persuading candidates to join their chains.

In fact, there are a number of rationales for supporting the idea that information should be carefully selected and that there is potential dilemma regarding the extent of information provided to potential franchisees (Sicilia and Ruiz 2010). Whereas the two first rationales below support publication restraint, the third advocates reporting more extensive information.

First, literature on interfirm relationships classifies contracts as formal and relational. Whereas formal contracts detail how to act in particular settings, relational contracts are agreements that rely on the value of future relationships and, hence, there is less formalization (Solís et al. 2017). Past evidence in franchising shows that more formalized contracts do not always lead to better results. In turn, relational contracts may enhance franchisee satisfaction (Combs et al. 2004). Associated with this classification, information 
posted on websites can be considered pre-contractual information (although it may but need not be the disclosure document), that is, a formal statement of certain facts. It represents voluntary release of relevant information to franchisee candidates. Although website information is not a contract, literature on contracting may suggest abstaining from giving out too much information.

Second, when designing website content, franchisors should bear in mind neuroscientists' findings that individuals forget most of the information they are given and that they pay more attention to messages that appeal to their emotions (Medina 2008). Additionally, individuals are better at identifying patterns than they are at recording details, so simple messages may be more effective to consolidate memories (Medina 2008). Their retention is volatile, as Medina (2008) might put it, so franchisors should carefully choose the contents of their websites. Additionally, psychology has shown that excessive information may be paralyzing (Schwartz 2004). As Speener and Freeman (2012) put it, the rising volume of marketing messages is overwhelming rather than empowering.

Third, signalling theory emphasizes that to attract resources, the informed party (i.e., the franchisor) must decide whether and how to reveal information (Michael 2009). Potential franchisees might intuit that reasons for withholding information might be because of unstated high entry fees, low profitability, weak chain growth, among others (Michael 2009; Sadeh and Kacker 2017), especially information referred to as objective facts, such as functional benefits. Therefore, there is an incentive to reveal information to franchisee candidates.

Franchisors aiming to increase audience awareness, with the objective of persuading some of them to join their chains, should take both these considerations and the sales funnel framework into account. This is especially relevant for franchisors that compete against each 
other by selling their business formats to franchisee candidates (Michael 2009; Zachary et al. 2011). Franchisors who want to generate interest in their franchise opportunities need to be able to initiate relationships with franchisee candidates. Effectively branding a franchise concept may help a company compete for talented candidates, which in turn can contribute to delivering quality to customers, as happens with other human resources (Rampl and Kenning 2014).

Thus, we expect that franchisors with better-designed value propositions have an advantage when it comes to growth. Our purpose is to empirically determine which propositions are relevant. Hence, our hypothesis:

H2: Information about functional benefits on franchisor websites has a positive relationship with franchise chain growth.

We have already argued that emotions help memory (Medina 2008). In this vein, candidates may move beyond looking at the functional benefits (product-related) and consider symbolic benefits (related to emotions, such as self or social esteem) when making a decision to become a franchisee or considering a particular brand (Aaker 2009). Previous literature outside of the topic of franchising shows that recruitment depends not only on functional benefits, such as pay, opportunities for careers, location or organizational structure, but also on symbolic benefits that candidates attribute to organizations (Lievens and Highhouse 2003). These benefits relate to perceptions of a company's prestige which, when the candidate becomes associated with the company, may help candidates attain some kind of social approval. These are even more important when instrumental differences between brands are scarce (Lievens and Highhouse 2003), as may occur in the competitive environment of franchising. 
Symbolic benefits, like brand image or prestige, are important in B2B markets such as franchising where tangible features do not play a noticeable role in product or service differentiation (Nyadzayo et al. 2016). These benefits also include organizational values and perceptions of person-company fit in terms of values and/or demographics. Franchisors seek to attract franchisee candidates who share similar values with their own chain (Zachary et al. 2011). This presocialization can prevent future agency problems and minimize adverse selection when franchisees independently make decisions that franchisors are unable to monitor (Minkler 1990; Zachary et al. 2011). In other words, with presocialization and selfselection, companies develop a certain type of workforce (Cable and Judge 1996; Nyadzayo et al. 2011).

Moreover, very often franchisee candidates are former customers and/or employees who have appreciated the franchise chain before considering it as a potential investment (Bradach 1998). Therefore, good customer service and good human resource practices produce positive externalities, thus attracting motivated candidates who already have certain knowledge about the business and can make informed decisions. As well, many candidates are attracted by the brand because of their families' and friends' experiences with the brand. Staff and other stakeholders can be seen as brand ambassadors who contribute to brand image (Nyadzayo et al. 2011).

Additionally, when offering a value proposition, franchisors may pursue candidates who prefer companies that have organizational attributes similar to their own personal values, so they try to determine if their degree of fit accords with the companies' (Cable and Judge 1996). Nyadzayo et al. (2011), Watson et al. (2016) and Zachary et al. (2011) have found that brand relationships and performance improve when franchisors select franchisees with a cultural fit to the company's vision. 
Finally, symbolic benefits may be especially relevant to single-unit franchisees who have no previous experience dealing with a franchisor and who tend to appreciate the nonfinancial aspects of franchise ownership (Grünhagen and Mittelstaedt 2005). They can deal, for instance, with the location of the store and the associated life-style as well as the possibilities of leveraging their personal social networks; or with the sought after profile that involves certain personality traits ${ }^{3}$.

Therefore, we expect that certain pieces of information on symbolic benefits or non financial aspects of franchise ownership relate to franchise growth. We will empirically identify which particular pieces are effective. Therefore, our hypothesis is the following:

\section{H3: Information about symbolic benefits on franchisor websites has a positive} relationship with franchise chain growth.

\subsubsection{Industry moderating effects}

Franchisee candidates evaluate the business potential (financial expectations) and its fit with their own abilities. In doing so, they must appraise a service (jump-start entrepreneurial activity) whose nature is intangible and difficult to assess. However, the information asymmetry between franchisors and franchisee candidates may be unequal in retail-type and pure service-type franchise chains. Retailing opportunities may be easier to assess because they commercialize a tangible product for final customers that backs franchisor proposals (Barthélemy 2008). On the other hand, quality of pure services is more difficult to disentangle and, furthermore, those services will be co-created with franchisees when sold to final customers (Perrigot, López-Fernández and Eroglu 2013).

\footnotetext{
${ }^{3}$ These items are included in the category of information labeled as "Recruitment process of franchisee candidates".
} 
When it comes to seizing a business opportunity, prospective franchisees interested in pure services may highly appreciate information that reduces their uncertainty regarding adverse selection as this assessment can be a complicated and demanding issue. From the point of view of the franchisor, it may be rewarding to highlight features that better shape the consistency of the service provided and the quality level of the business opportunity.

We considered three categories of functional information that could reduce these information asymmetries. First, franchisors could post information on training programs (initial assistance and continuous assistance) available to reduce the franchisees' uncertainty about their ability to run a business. Past literature in franchising has used training programs as a proxy for tacit business practices (Combs et al. 2011; López-Fernández and López-Bayón 2017; Mundziev and Windsperger 2011; Windsperger 2004) that are acquired through experience or face-toface training (Barthélemy 2008; Windsperger 2004). Additionally, training has been considered an indicator of quality in franchising (Kaufmann and Dant 2001; Sadeh and Kacker 2017). Secondly, a statement of business potential (financial expectations) could help franchisees gain insight into the business opportunity. Financial disclosure made on a voluntary basis has been studied as a signal of quality in franchising (Michael 2009; Sadeh and Kacker 2017).

Finally, we consider a business's certification of quality to be a symbolic benefit that is particularly appreciated in pure services. These certifications may assure prospective franchisees that they are dealing with businesses that have been acknowledged for their excellence when considering investment. More qualified franchisors should have no problem gaining certifications of quality (Sadeh and Kacker 2017) and, as achieving that recognition requires active effort, franchisors may be interested in signalling their accomplishments. 
Hence, we propose the following interactions regarding the above mentioned effects and the industry:

H4: The industry moderates the specific relationship between information about assistance (H4a: initial assistance, H4b: continuous assistance) and franchise chain growth so that services will enhance the positive relationship between these categories of information and franchise chain growth.

H5: The industry moderates the specific relationship between information about business potential (financial expectations) and franchise chain growth so that services will enhance the positive relationship between these categories of information and franchise chain growth.

H6: The industry moderates the specific relationship between information about certifications and franchise chain growth so that services will enhance the positive relationship between these categories of information and franchise chain growth.

\section{METHODOLOGY}

\section{1. Empirical context and sample of franchise chains}

The choice of the French market for the empirical context of our research was based on several rationales. First, France is the oldest and largest market in Europe in terms of franchising. More specifically, in 2016, there were 1,900 franchisors with 71,508 franchised stores generating $€ 55.10$ billion of total sales in France (French Franchise Federation, 2017)

Second, regarding our topic of interest in a broad sense, i.e., franchise chain growth through the opening of new franchised stores, France serves as a good empirical setting due to its annually growing franchise sector, e.g., $+2.91 \%$ in 2015-2016 (French Franchise Federation, 
2017). Our empirical study deals with a sample of 106 franchise chains in both retail and service industries in the French market. These 106 chains correspond to all the chains that have at least one franchised store and that have had positive growth ${ }^{4}$ over the 2012- 2013 period.

\subsection{Data and variables}

We gathered data in two ways: 1) through a detailed analysis of the content of franchisor websites; and 2) the use of secondary data on franchise chain characteristics and growth.

\subsubsection{Detailed observation of the content of franchisor websites}

A detailed analysis of the website content of 106 franchise chains was conducted in July 2012. By franchisor website, we refer to a franchise chain's home page on the Internet and all links that the franchise chain associates with its home page (Cable and Yu 2006). For this detailed analysis, we used a codebook we developed using a three-step process. First, we reviewed the existing literature on website content dealing with recruitment of franchisee candidates (e.g., Cedrola and Memmo 2009; Dixon and Quinn 2004; Rao and Frazer 2006; Young, McIntyre and Paswan 2004; Zachary et al. 2011). Second, we conducted a preliminary observation of a sample of franchisor websites. This benchmarking step allowed us to list all the types of information displayed on franchisor websites that could be of interest to franchisee candidates and to distinguish between functional and symbolic benefits following the pattern shown above (del Río, Vázquez and Iglesias 2001) in figure 1. Particularly, information usually included in disclosure documents was considered as

\footnotetext{
${ }^{4}$ We limited our study to growing franchise chains, because we consider that the chains that are willing and able to increase the number of franchised stores will make an effort to recruit new franchisees. Of course, nongrowing franchise chains may be interested in attracting franchisee candidates for renewal, but we expect this effort to be marginal.
} 
functional. Thirdly, we asked franchising experts, including researchers and franchisors and franchise staff, to validate this list of types of information and their classification into categories. The codebook with functional and symbolic benefits contains eighteen categories displayed in Table 1.

\section{Insert Table 1 about here}

For each of the eighteen categories, we measured the extent of information provided to franchisee candidates on the franchisor websites and summed up the related items. For instance, for the category "information on the franchise chain," we took into account the six following types of information: 1 ) whether there was a detailed description of the concept; 2 ) a definition of franchising; 3) mention of the year the franchise chain was established; 4) a description of the chain's history; 5) the number of franchised stores; 6) the number of company-owned stores. For each of these six types of information, we used the unity value when the information was displayed on the website and the zero value when the information was not provided on the website. An average score across websites was computed for each category. We did the same for the eighteen categories ( 9 functional benefits and 9 symbolic benefits). We thus had values ranging from 0 to 1 , indicating the extent of information provided on the franchisor websites to the franchisee candidates. Descriptive statistics for these eighteen categories of information are displayed in Table 2.

\section{Insert Table 2 about here}

\subsubsection{Use of secondary data on chain characteristics and growth}

The secondary data on franchise chain characteristics and growth were taken from the franchise directories, Toute la franchise, les chiffres, les textes, les réseaux, for the years 2013 and 2014 published by the French Franchise Federation (corresponding to the 2012 and 2013 
data). This data source displays the main characteristics of franchise chains in the French market. These directories have been used in previous research on franchising in France (e.g., Barthélemy 2008; Dant, Perrigot and Cliquet 2008; El Akremi, Mignonac and Perrigot 2011; Perrigot, López-Fernández and Eroglu 2013) and have proven to be a reliable source of information.

From this source, we computed the chain growth of franchised stores over a one-year period, 2012-2013. Additionally, for our 106 sampled franchise chains, we used the following characteristics as control variables consistent with the extant franchising literature (e.g., Michael 2000a; Barthélemy 2008; López-Bayón and López-Fernández 2016): chain age, chain size, percentage of company-owned stores within the chain, industry and international dimension, as displayed in the 2013 directory and corresponding to the 2012 data.

In more detail, chain age was computed from the year the concept was franchised (and not the year the company first went into business). The mean age of our sampled chains was 11.24 years (standard deviation: 10.55). Chain size refers to the number of franchised and companyowned stores within the chain in the French market. The mean size of our sampled chains was 87.69 stores (standard deviation: 122.61). The average percentage of company-owned stores within the chain in the French market equals $28.36 \%$ (standard deviation: 26.15). The industry in which the franchisor operates its business is coded as follows: 0 for retailing and 1 for services. In our sample, $67 \%$ of the chains were in the service industry. The international dimension of the chain is coded as follows: 0 for purely-domestic chains and 1 for international chains. In our sample, $43 \%$ of the chains were international chains. The one-year chain growth corresponds to the number of franchised stores opened in one year, i.e., the number of franchised stores in 2013 minus the number of franchised stores in 2012. The 
average one-year chain growth equals 10.99 franchised stores (standard deviation: 17.34).

Descriptive statistics for these variables are displayed in Table 3.

Insert Table 3 about here

\subsection{Data analyses}

In addition to descriptive data analyses, we used a linear regression model to examine the relationships between the extent of information provided on the franchisor websites for the eighteen categories and the franchise chain growth, controlling for chain characteristics. The model can be written as follows:

Franchise chain growth=

(Controls) $\quad b_{0}+b_{1}($ chain age $)+b_{2}$ (chain size $)+b_{3}$ (percentage of company-owned stores within the chain $)+b_{4}($ industry $)+b_{5}($ international dimension $)+$

(Moderating variables $) \quad b_{6}($ industry*initial assistance $)+b_{7}($ industry*continuous assistance $)+b_{8}($ industry*business potential (financial expectations))+ $b_{9}($ industry*certifications)

(Predictors) $\quad \sum \mathrm{b}_{\mathrm{i}}\left(\right.$ extent of information provided on the website for category $\mathrm{x}_{\mathrm{i}}$ )

To reduce potential problems with multicollinearity between the interaction terms and their components, we performed the mean-centering procedure suggested by Aiken and West (1991). The Variance Inflation Factors (VIFs) were no larger than three, thus indicating very little likelihood of any multicollinearity in the parameter estimates (Hair et al. 2009).

\section{RESULTS}

\subsection{Extent of information provided on franchisor websites}


The values corresponding to the extent of information for the eighteen categories are displayed in Table 2. These values vary from 0.14 for certificates to 0.36 for aesthetic aspects of the website. This concretely means that at present franchisors provide up to a maximum of $36 \%$ of the information that could be included on their websites to attract franchisee candidates.

\subsection{Extent of information provided on franchisor websites and franchise chain growth}

Estimation results of the linear regression model are presented in Table 4. Model 0 includes the control variables only. Model 1 includes the variables of interest (extent of information for the eighteen categories). These variables explain additional variance (adjusted $\mathrm{R}^{2}$ went from 0.197 to 0.317 ). Model 2 adds the moderating effects (adjusted $\mathrm{R}^{2}$ : 0.349). Although there is still much unexplained variance, we assume that many other factors have an impact on franchise chain growth. In fact, the information provided on the websites represents only the first step in incorporating new franchisees. A second step may include personal interviews, for example. Even though information on websites has an influence on attracting franchisee candidates, as Stephens (2007) proposes, complementary information means (e.g., face-toface meetings, brochures) increase the likelihood of attracting an audience.

\section{Insert Table 4 about here}

Overall, as detailed below, in model 1 we observe that three categories of information have a significant and positive relationship with franchise chain growth, so "H1: Display of information targeting franchisee candidates on franchisor websites has a positive relationship with franchise chain growth." is supported. Franchisee candidates can use websites to become more knowledgeable about the franchise and then determine whether or not to proceed interactively (Stephens 2007). This result supports the idea that this form of mass media can 
be a precursor to further contact with franchises and ultimately chain growth. However, as discussed below, many categories have a negligible or even negative relationship with franchise chain growth.

More specifically, regarding functional benefits, two out of nine categories of information have a significant and positive relationship with franchise chain growth. Firstly, the extent of information provided concerning financial requirements needed to join the chain has a significant (at 5\%) and positive relationship with franchise chain growth $[$ coef $=16.617 ; \mathrm{p}=$ .014]. Secondly, the extent of information on possibilities of contact without interaction has a significant (at 5\%) and positive relationship with franchise chain growth $[$ coef $=15.790 ; p=$ .048]. This category includes contents that are ready to download and/or subscribe to that may help candidates further research the features of the business. Therefore, it provides sequential insights into the business opportunities by going through the purchasing funnel. Finally, as far as the extent of information on business potential (financial expectations) is concerned, it has a significant (at 5\%) and negative relationship with franchise chain growth [coef $=-14.542 ; \mathrm{p}=.018]$ contrary to $\mathrm{H} 2$. One possible explanation for the negative relationship is that franchisee candidates do not give credence to the information provided or the content does not match their own expectations regarding resource compensation resulting in a reduced chain growth. In the latter case, it may happen that prospective franchisees are more demanding or that they find those results out of their reach. Michael (2009) remarks that prospective franchisees do not always encourage the revelation of financial information. In fact, most of the sampled franchisors do not offer this kind of information and still recruit franchisees. Michael (2009) hypothesizes that some franchisee candidates may find information assessment costly and therefore prefer to settle for incomplete information on this topic. As a conclusion, "H2: Information about functional benefits on franchisor websites has 
a positive relationship with franchise chain growth" is only partially supported with two categories of information having a significant and positive effect on growth, and one category having a significant and negative effect.

Regarding symbolic benefits, only one out of nine categories of information has a significant and positive relationship with franchise chain growth. The extent of information on the recruitment process of franchisee candidates has a significant (at 10\%) and positive relationship with franchise chain growth [coef $=-4.842 ; \mathrm{p}=0.098$ ]: "H3: Information about symbolic benefits on franchisor websites has a positive relationship with franchise chain growth" receives limited support.

Cable and Judge (1996) found that subjective perceptions of fit between organizations and job candidates significantly predict job choice intentions as other important aspects of the job (e.g., rewards). Therefore, information about the recruitment process may help persuade prospective franchisees and ultimately enhance franchise chain growth. However, the findings showing that functional benefits affect franchise chain growth more often as compared to their symbolic counterparts goes in line with Lilis et al. (2010) and Candi and Kahn (2016) findings. These authors reported that the relationship between functional benefits and customer satisfaction in $\mathrm{B} 2 \mathrm{~B}$ markets is linear, whereas, other benefits linked to emotions are not, or they influence buyers only after some functionality is reached.

In model 2, we introduced the interaction variables. Employing a contingency logic on the effect of information that signals assistance (initial and continuous), business potential (financial expectations) and certifications, we explored a more refined interpretation of the effects of displaying this kind information. Specifically, we tried to ascertain whether franchise chains that offer services in the consumer market need to post this information on their websites, because services are more difficult to assess than products. We found support 
for the hypothesis "H4b: The industry moderates the specific relationship between information about continuous assistance and franchise chain growth so that services will enhance the positive relationship between these categories of information and franchise chain growth" $[$ coef $=32.687 ; \mathrm{p}=0.089]$. Therefore, employing a contingency logic (interaction terms) on the effect of the industry on franchise chain growth adds insight according to the significant interactive effect obtained. Specifically, without the interaction term, one plausible conclusion would be that mentioning continuous assistance is useless in terms of growth. However, the positive interaction effect between this variable and the industry suggests a subtler interpretation of the effects of displaying this information. Finally, there was no support for the hypotheses H4a in link with initial assistance, H5 with business potential (financial expectations) and H6 with certifications. Indeed, there is not any difference in the impact of these variables contingent on the industry. Business potential (financial expectations) negatively affect franchise chain growth in all industries; and initial assistance and certifications do not significantly affect growth. We speculate that candidates may take initial assistance for granted, so information on such initial assistance does not affect their intention to join the chain. Moreover, we consider that certifications are less relevant for candidates than the value of the brand. Indeed, they are not widely used in franchising.

As far as control variables are concerned, chain size had a significant (at 1\%) and positive relationship with franchise chain growth $[$ coef $=.067 ; p=0.000]$ and the percentage of company-owned stores within the chain had a significant (at 1\%) and negative relationship with franchise chain growth [coef $=-.215 ; \mathrm{p}=0.004]$. The industry and the international dimension of the chain did not have any significant relationship with franchise chain growth.

\section{DISCUSSION}

\subsection{Summary of findings}


Attracting franchisee candidates to a chain is a major problem in franchising (Jambulingam and Nevin 1999, Watson et al. 2016) due to the long term nature of the franchise contract and because recruiting franchisees means attracting entrepreneurs who commit capital, effort and time (Zachary et al. 2011) and who are not merely employees. However, published research on this topic is still sparse (Clarkin and Swavely 2006; Jambulingam and Nevin 1999, Watson et al. 2016). Moreover, little is known about the effectiveness of websites in recruiting franchisee candidates, despite the pervasiveness of this practice.

Franchising provides a natural field for analyzing recruitment of contractual partners in B2B relationships. On the one hand, franchisors repeat this action with every franchisee. On the other hand, contracts tend to remain stable over time (Cochet and Garg 2008). In fact, outside of franchising, parties rarely sign contracts with different partners within the same standardized business (Solís et al. 2017), so they do not advertise business opportunities as widely on websites (e.g., joint-ventures or strategic alliances). Therefore, analyzing recruiting information on franchisor websites provides a unique unexplored opportunity to study website effectiveness on $\mathrm{B} 2 \mathrm{~B}$ or interorganizational relationships.

Given this background and building on the marketing and franchising literature, this paper examines the relevance of the information displayed on franchisor websites and its relation to chain growth. This analysis reveals the contents of websites that are most effective in attracting potential franchisees and discusses the contribution of this information to franchise branding, differentiating between functional and symbolic dimensions in terms of attracting franchisee candidates.

First of all, our empirical study underscores the importance of websites in initiating franchisee attraction. As has been shown, there is a significant link between certain categories of information and growth of franchise chains. This early stage of franchisor-franchisee 
communication deserves close attention from franchisors to more effectively attract new partners. This result is consistent with Cable and Yu's (2006) findings that indicate that beliefs about organizational identity (franchise brand in our context) are formed even before recruitment.

Secondly, our results indicate that franchisor websites do not report extensive information to franchisee candidates. Indeed, for each of the eighteen categories of information, at best, franchisors include only one third of the information they could display on their websites to attract franchisee candidates. This result is in line with evidence regarding the existence of an optimal range of information in online consumer markets (Sicilia and Ruíz 2010). However, the amount of information provided should be restricted to appropriate topics.

We observed that the frequent appearance of certain categories of information has no correlation to chain growth. In fact, many franchisors do not display categories of information that significantly impact chain growth. Hence, the scarcity of significant categories may reflect the loss of opportunities, because franchisors are not taking advantage of how information displayed can entice potential franchisees.

As shown in our codebook exhibited in Table 1, some of the significant categories (in bold) receive little attention by franchisors on their websites, which advocates a rethinking of how they craft their communication. Between $23.6 \%$ and $66 \%$ of the analyzed websites do not contain anything regarding the categories of information that significantly impact chain growth. For instance, $42.45 \%$ of these websites do not report the financial requirements needed to join the chain. This lack of information is particularly surprising as it is usually publicized by professional brokers in franchising, therefore, there are no obvious reasons to omit it (Sadeh and Kacker 2017). 
Thirdly, the extent of information provided to franchisee candidates on franchisor websites has a significant and positive relationship with franchise chain growth in three out of the eighteen categories of information, and an additional one for service-type franchise chains. These include information dealing with functional benefits: information on the financial requirements for joining the chain, on possibilities of contact without interaction and on continuous assistance for service-type franchise chains, as well as with a symbolic benefit: information on the recruitment process of franchisee candidates. In fact, both types of benefits are intertwined in franchising, as observed in consumer markets (del Río et al. 2001; Aaker 2009). In order to create a singular franchise brand that attracts new franchisee candidates and provides a competitive advantage, franchisors should consider these symbolic b3enefits apart from the most obvious functional ones.

Fourthly, another category has a counterintuitive relationship with franchise chain growth. Indeed, the extent of information about business potential (financial expectations) has a significant but negative relationship with franchise chain growth. We speculate that providing too much information about the business potential may deter some franchisee candidates who anticipate that the business will not fulfill their expectations or who think they do not have the right profile to achieve those yields. However, these results do not immediately mean that the inclusion of this information is detrimental. In the case where franchisors are interested in particular franchisee profiles that demand careful screening, it could be advantageous to post this information so as to eliminate unsuitable franchisee candidates (by self-selection) and avoid future misunderstandings.

Fifthly, information about continuous assistance was found to have a significant and positive effect on franchise chain growth in the case of service-type franchise chains. Franchisors periodically train franchisees to update their business models and maintain their competitive 
edge (Michael and Combs 2008; Barthélemy 2008). Results suggest that information on continuous assistance is particularly appreciated by those candidates interested in intangible concepts where quality is more difficult to guarantee and to keep consistent. These programs also facilitate developing personal ties and socialization (Michael 2000), so they also connect with symbolic benefits.

We identified thirteen other categories of information that have no significant relationship with franchise chain growth. Franchisors may ponder these categories, taking into account the harmful effect of information overload on decision-makers in consumer markets, as well as other items advanced in the literature section (Schwartz 2004; Sicilia and Ruíz 2010; Speener and Freeman 2012).

Overall, increasing the effectiveness of website information is linked to improving quality, since usefulness is a feature of quality information (Rieh 2002) and the purpose of attracting new franchisees is to promote chain growth.

\subsection{Contributions to research}

This research contributes to the literature on marketing communication, franchising and B2B relationships. First, we contribute to the research on marketing communication by examining the effectiveness of websites in communicating B2B opportunities, and more specifically franchise business opportunities and identifying relevant categories of information to be displayed. This identification is particularly valuable because, on the Internet, the potential to increase amounts of information is almost unlimited (Sicilia and Ruíz, 2010). In this way, our study answers Ratchford's (2015) call for research on online communication and Varadarajan and Yadav's (2009) remarks about the limited empirical research available on communication and interaction with businesses. 
Second, we link this research with the literature on franchising, as Lafontaine (2014) has called for more research on the adoption of new technologies in franchised chains. Our study extends in this direction and builds on academic works dealing with franchising and communication on the Internet and on social media (e.g., Kacker and Perrigot 2016; Perrigot et al. 2012) or on CSR activities (e.g., Perrigot, Oxibar and Déjean 2015). Until recently, research on the role of franchisor online communication in attracting franchisees has mainly dealt with the percentage of franchisors using their websites to provide information to franchisee candidates (e.g., Dixon and Quinn 2004; Rao and Frazer 2006; Young, McIntyre and Paswan 2004), the types of information provided on franchisor websites (e.g., Cedrola and Memmo 2009; Rao and Frazer 2005; 2006) and the determinants of such franchisor online communication in terms of industry (e.g., Cedrola and Memmo 2009; Dixon and Quinn 2004;), chain size (e.g., Rao and Frazer 2006; Young, McIntyre and Paswan 2004) or the percentage of company-owned stores (Young, McIntyre and Paswan 2004). Furthermore, our study also completes the case study on Subway's means of communication to attract franchisee candidates (Perrigot, Basset and Cliquet 2011) and the study of the importance of personal characteristics in franchisee selection (Clarkin and Swavely 2006; Nyadzayo et al. 2011). As discussed, our empirical study focuses on the French market; it answers the call from Dant (2008) and Dant, Perrigot and Cliquet (2008) for more empirical research on franchise chains outside Anglo-Saxon countries.

Third, in response to Michael (2009), this research empirically determines what signals are actually used by franchisors when recruiting and how they are interpreted by the candidates. We contribute to this understanding by analyzing the nature and extent of information commonly displayed on websites. Our results suggest that signaling both functional and 
symbolic benefits affects franchisee candidates' decisions and, ultimately, franchise chain growth.

This paper also contributes to the study of Internet practices in B2B relationships (Nyadzayo et al. 2016) by focusing on franchisor-franchisee candidate relationships. This is a particular setting because B2B opportunities are not commonly announced in the mass media.

In short, this is the first study to address the content of recruiting information displayed on franchisor websites in connection with its effectiveness on chain growth. This study pioneers classifying information according to its functional and symbolic benefits and relating it to franchise branding, thereby expanding the previous literature on franchisee recruiting and organizational identity (Watson et al. 2016; Zachary et al. 2011).

\subsection{Contributions to the practice}

Our research has some managerial implications. First, the relatively low mean values for the significant categories (out of the unity value) and particularly the high number of 0 values in these categories across the franchisor websites reveal that there is room for improvement to optimize the content of franchisor websites in order to better attract franchisee candidates. Second, and in accordance with the first point, our codebook, with the eighteen categories divided into functional and symbolic benefits and all the associated types of information, could be used by franchise experts and franchisors as an operational tool for auditing and improving website content directed towards attracting franchisee candidates. Third, franchisors could consider omitting information that may have a negative impact on franchise chain growth, though it can signal complex and demanding franchise concepts and may provide a better pool of candidates. Fourth, reducing information that does not have any statistically significant relationship with franchise chain growth would be advisable. This 
latter information may obscure the value proposition without having any positive effect.

Franchisors can convey information not detailed on the franchisor website during further steps of the recruitment process, for instance, during face-to-face meetings. Overall, our results may help franchisors brand their business opportunities online, thereby making them appealing to their target segment of franchisee candidates.

\subsection{Limitations and tracks for future research}

This research has some limitations and also offers some tracks for future research. First, using data available on the Internet from a cross-sectional perspective, and more specifically observing website content, presents some shortfalls. This is only a snapshot at time $\mathrm{t}$ and website contents may have evolved since this observation. Second, we used Internet data, i.e., secondary data. Complementary approaches, either qualitative ones involving in-depth interviews with franchisors or quantitative ones involving questionnaire-based surveys with franchisors, could be very meaningful for obtaining more insight on franchisor choices with regards to designing the part of their websites dedicated to franchisee candidate recruitment. Third, our regression models run on a sample of 91 franchisors and involving over 20

independent variables show a limited explanatory power with $\mathrm{R}^{2}$ values of $31.7 \%$ and $34.9 \%$. We thus explain about a third of the variation of franchise chain growth with the information provided on franchisor websites. Other factors could be considered in future research, for instance, information provided during face-to-face meetings with the franchisor, information provided through the other franchisees of the chain or information provided in the franchise disclosure document. Fourth, our research deals with the French market only. Extending the empirical study to other European markets or comparing findings from France and another markets, such as the United States, as other authors have done in the case of plural form or 
chain internationalization, would be of interest (Dant, Perrigot and Cliquet 2008) (Perrigot, López-Fernández and Eroglu 2013).

\section{ACKNOWLEDGEMENTS}

The authors acknowledge the French National Research Agency (FRANBLE - ANR-12BSH1-0011-01), the Spanish Ministry of Economy and Competitiveness (ECO2017-85704-R), as well as the Center in Franchising, Retail \& Service Chains for their valuable support. 


\section{REFERENCES}

Aaker, David A. (1991), Managing brand equity, New York, NY: Free Press.

Aaker, David A. (2009), "Beyond functional benefits," Marketing News, September, 30, 23.

Abell, Mark (2016), "Legal perspective of the regulatory framework and challenges for franchising in the EU," Study for the IMCO Committee of the European Parliament, [available at http://www.europarl.europa.eu/supporting-analyses (accessed 29 June 2017)].

Aiken, Leona and Stephen G. West (1991), Multiple regression: Testing and interpreting interactions. Newbury Park, CA: Sage Publications.

Albert, Stuart and David. A. Whetten (1985), "Organizational identity," Research in Organizational Behavior, 7, 263-295.

Altinay, Levent and Fevzi Okumus (2010), "Franchise partner selection decision making," The Service Industries Journal, 30, 6, 929-946.

Ambrose, Eamonn, Donna Marshall, Brian Fynes, and Daniel Lynch (2008), "Communication media selection in buyer-supplier relationships," International Journal of Operations \& Production Management, 28, 4, 360-379.

Banque Populaire study (2016), "Synthèse 2015 Enquête annuelle de la franchise," [available at: http://www.franchise-fff.com/base-documentaire/finish/53/3903.html (accessed 25 July 2017)].

Barber, Alison E. (1998), Recruiting employees: Individual and organizational perspectives, Thousands Oaks, CA: Sage. 
Barry, Bruce and Ingrid S. Fulmer (2004) “The medium and the message: The adaptive use of communication media in dyadic influence," Academy of Management Review, 29, 2, 272-292.

Barthélemy, Jérémy (2008), “Opportunism, knowledge, and the performance of franchise chains," Strategic Management Journal, 29, 1451-1463.

Bradach, Jeffrey L. (1997), "Using the plural form in the management of restaurant chains," Administrative Science Quarterly, 42, 2, 276-303.

Bradach, Jeffrey L. (1998), Franchise organizations, Boston, MA: Harvard Business.

Cable, Daniel M. and Timothy A. Judge (1996), "Person-organization fit, job choice decisions, and organizational entry," Organizational Behavior and Human Decision Processes, 67, 3, 294-311.

Cable, Daniel M. and Kang Y.T. Yu (2006), "Managing job seekers' organizational image beliefs: The role of media richness and media credibility," Journal of Applied Psychology, 91, $4,828-840$.

Candi, Marina and Kenneth B. Kahn (2016), "Functional, emotional, and social benefits of new B2B services,” Industrial Marketing Management, 57, 177-184.

Cedrola, Elena and Sabrina Memmo (2009), “Internet for franchising: Current use and areas of improvement—results of an empirical research," Journal of Euromarketing, 18, 1, 5-21.

Clarkin, John E. and Steven M. Swavely (2006), “The importance of personal characteristics in franchisee selection,” Journal of Retailing and Consumer Services, 13, 133-142.

Cochet, Olivier and Vinay K. Garg (2008), "How do franchise contracts evolve? A study of three German SMEs,” Journal of Small Business Management, 46, 134-151. 
Combs, James G., Steven C. Michael, and Gary J. Castrogiovanni (2004), “Franchising: A review and avenues to greater theoretical diversity," Journal of Management, 30, 6, 907-931.

Combs, James G., David. J. Jr. Ketchen and Jeremy C. Short (2011), "Franchising research: Major milestones, new directions, and its future within entrepreneurship," Entrepreneurship Theory and Practice, 35, 3, 413-425.

Dant, Rajiv P. (2008), “A futuristic research agenda for the field of franchising,” Journal of Small Business Management, 46, 1, 91-98.

Dant, Rajiv P. and Paul D. Berger (1996), "Modelling cooperative advertising decisions in franchising," The Journal of the Operational Research Society, 47, 9, 1120-1136.

Dant, Rajiv P., Rozenn Perrigot, and Gérard Cliquet (2008), “A cross-cultural comparison of the plural forms in franchise networks: USA, France, and Brazil," Journal of Small Business Management, 46, 2, 286-311.

Dixon, Helen and Barry Quinn (2004), "Franchising and the Internet: An exploratory study of franchisor web sites," Internet Research, 14, 4, 311-322.

El Akremi, Assâad, Karim Mignonac, and Rozenn Perrigot (2011), “Opportunistic behaviors in franchise chains: The role of cohesion among franchisees," Strategic Management Journal, $32,930-948$.

El Akremi Assâad, Olivier Herrbach, Karim Mignonac, Rozenn Perrigot, and Kelly Prioux (2012), Formation de la relation de franchise : Processus et déterminants, Fédération Française de la Franchise. 
French Franchise Federation (2017), “Les chiffres-clés en France,” [available at: http://www.franchise-fff.com/franchise/les-chiffres-cles (accessed 25 July 2017)].

Garrigos Simon, Fernando J., Rafael Lapiedra Alcamí, and Teresa Barberá Ribera (2012), "Social networks and Web 3.0: their impact on the management and marketing of organizations," Management Decision, 50, 10, 1880-1890.

Grünhagen, Marko and Robert A. Mittelstaedt (2005), "Entrepreneurs or investors: do multi-unit franchisees have different philosophical orientations?," Journal of Small Business Management, 43, 3, 207-225.

Hair, Joseph F., William C. Black, Barry J. Babin, and Rolph E. Anderson (2009), Multivariate Data Analysis, Upper Saddle River, NJ: Prentice-Hall.

IFA, International Franchise Association (2016), "Franchise businesses to continue growth trend in 2016, outpacing economy-wide pace", [available at: http://www.franchise.org/franchisebusinesses-to-continue-growth-trend-in-2016-outpacingeconomy-wide-pace (accessed 29 June 2017)].

Jambulingam, Thani and John R. Nevin (1999), "Influence of franchisee selection criteria on outcomes desired by the franchisor," Journal of Business Venturing, 14, 363-95.

Kacker, Manish and Rozenn Perrigot (2016), "Retailer use of a professional social media network: Insights from franchising," Journal of Retailing and Consumer Services, 30, $222-$ 233.

Kaufmann, Patrick J. and Rajiv. P. Dant (1996), “Multi-unit franchising: Growth and management issues," Journal of Business Venturing, 11, 5, 343-358. 
Kaufmann, Patrick J. and Rajiv P. Dant (2001), "The pricing of franchise rights," Journal of Retailing, 77, 4, 537-545.

Lafontaine, Francine (1992), “Agency theory and franchising: Some empirical results,” Rand Journal of Economics, 23, 2, 263-283.

Lafontaine, Francine (1993), “Contractual arrangements as signaling devices: evidence from franchising," Journal of Law, Economics, \& Organization, 9, 2, 256-289.

Lafontaine, Francine (2014), "Franchising: Directions for future research," International Journal of the Economics of Business, 21, 1, 21-25.

Lievens, Filip and Michael M. Harris (2003), "Research on Internet recruiting and testing: Current status and future directions," International Review of Industrial and Organizational Psychology, 18, 131-165.

Lievens, Filip and Scott Highhouse (2003), "The relation of instrumental and symbolic attributes to a company's attractiveness as an employer," Personnel Psychology, 56, 75-102.

Lilien, Gary L., Rajdeep Grewal, Douglas Bowman, Min Ding, Abbie Griffin, Viswanathan Kumar, Das Narayandas, Renana Peres, Raji Srinivasan, and Qiong Wang (2010), "Calculating, Creating, and Claiming Value in Business Markets: Status and Research Agenda," Marketing Letters, 21, 287-299.

López-Bayón, Susana and Begoña López-Fernández (2016), “Partner empowerment and relationship failure in franchising," Journal of Small Business Management, 54, 4, 1059-1079. Martin, Dan. (1999), "Real world Internet applications that franchise companies actually use," Franchise World, 31, 4, 22-26. 
Medina, John J. (2008), Brain rules: 12 principles for surviving and thriving at work, home, and school, Seattle, Washington.

Michael, Steven C. (2000a), "Investments to create bargaining power: The case of franchising," Strategic Management Journal, 21, 4, 497-514.

Michael, Steven C. (2000b), "The effect of organizational form on quality: the case of franchising," Journal of Economic Behavior \& Organization, 43, 3, 295-318.

Michael, Steven C. (2009), "Entrepreneurial signaling to attract resources: the case of franchising," Managerial and Decision Economics, 30, 6, 405-422.

Michaelson, David and Don W. Stacks (2011), "Standardization in public relations measurement and evaluation standardization,” Public Relations Journal, 5, 2, 1-22.

Minkler, Alanson. (1990), “An empirical analysis of a firm's decision to franchise," Economics Letters, 34, 1, 77-82.

Norton, Seth W. (1988), "Franchising, brand name capital, and the entrepreneurial capacity problem," Strategic Management Journal, 9, S1, 105-114.

Nyadzayo, Munyaradzi W., Margaret J. Matanda, and Michael T. Ewing (2011), “Brand relationships and brand equity in franchising," Industrial Marketing Management, 40, 7 , 1103-1115.

Nyadzayo, Munyaradzi W., Margaret J. Matanda, and Michael T. Ewing (2016), “Franchiseebased brand equity: The role of brand relationship quality and brand citizenship behaviour," Industrial Marketing Management, 52, 163-174. 
Padgett, Dan and Douglas Allen (1997), “Communicating experiences: A narrative approach to creating service brand image," Journal of Advertising, 26, 49-62.

Perrigot, Rozenn, Guy Basset, and Gérard Cliquet (2011), "Multi-channel communication: The case of Subway attracting new franchisees in France," International Journal of Retail \& Distribution Management, 39, 6, 434-455.

Perrigot, Rozenn, Manish Kacker, Guy Basset, and Gérard Cliquet (2012), “Antecedents of early adoption and use of social networks for stakeholder communications: Evidence from franchising," Journal of Small Business Management, 50, 4, 539-565.

Perrigot, Rozenn, Begoña López-Fernández and Sevgin Eroglu (2013), “Intangible resources and plural form as drivers of franchise internationalization: Examination within a two-country perspective,” Journal of Small Business Management, 51, 4, 557-577.

Perrigot, Rozenn, Bruno Oxibar and Frédérique Déjean (2015), “Corporate Social Disclosure in the franchising sector: Insights from French franchisors' websites," Journal of Small Business Management, 53, 2, 321-339.

Rampl, Linn V. and Peter Kenning (2014), "Employer brand trust and affect: Linking brand personality to employer brand attractiveness," European Journal of Marketing, 48, 1/2, 218236.

Rao, Sally and Lorelle Frazer (2005), "The use of Internet-based technologies in Australian franchise systems: A preliminary study," Journal of Internet Business, 2, 1-17.

Rao, Sally and Lorelle Frazer (2006), “Australian franchisor websites: Moving towards network behavior," Journal of Theoretical and Applied Electronic Commerce Research, 1, 1, $56-64$. 
Ratchford, Brian T. (2015), "Some directions for research in interactive marketing," Journal of Interactive Marketing, 29, v-vii.

Rieh, Soo Y. (2002), "Judgment of information quality and cognitive authority in the Web," Journal of the Association for information Science and Technology, 53, 2, 145-161.

del Río, Ana Belén, Rodolfo Vázquez, and Victor Iglesias (2001), “The role of the brand name in obtaining differential advantages," Journal of Product \& Brand Management, 10, 7, $452-465$.

Sadeh, Farhad and Manish Kacker (2017), "Quality signaling through ex-ante voluntary information disclosure in entrepreneurial networks: evidence from franchising," Small Business Economics, doi: 10.1007/s11187-017-9892-4

Schwartz, Barry (2004), The paradox of choice: Why less is more. New York: Ecco.

Sen, Kabir C. (1998). "The use of franchising as a growth strategy by US restaurant franchisors," Journal of Consumer Marketing, 15, 4, 397-407.

Shane, Scott A. (1998), "Research notes and communications: Making new franchise systems work," Strategic Management Journal, 19, 7, 697-707.

Sicilia, Maria and Salvador Ruiz (2010), "The effect of web-based information availability on consumers' processing and attitudes," Journal of Interactive Marketing, 24, 1, 31-41.

Solís-Rodríguez, Vanessa, Manuel González-Díaz, Susana López-Bayón and Marta Fernández-Barcala (2017), "Why relational contracting is useless in some repetitive inter-firm relationships. Different learning effects in franchising contracts," Proceedings of the $27^{\text {th }}$ 
Asociación Científica de Dirección y Economía de la Empresa (ACEDE) Conference, Aranjuez, Spain.

Spenner, Patrick and Karen Freeman (2012), To keep your customers, keep it simple, Harvard Business Review, May.

Stephens, Keri K. (2007), “The successive use of information and communication technologies at work," Communication Theory, 17, 4, 486-507.

Varadarajan, Rajan and Manjit S. Yadav (2009), "Marketing strategy in an internet-enabled environment: a retrospective on the first ten years of JIM and a prospective on the next ten years," Journal of Interactive Marketing, 23, 1, 11-22.

Watson, Anna, Lola Dada, Marko Grunhagen, and Melody L. Wollan (2016), “When do franchisors select entrepreneurial franchisees? An organizational identity perspective," Journal of Business Research, 69, 12, 5934-5945.

Weaven, Scott, Lorelle Frazer, and Jeff Giddings (2010), "New perspectives on the causes of franchising conflict in Australia," Asia Pacific Journal of Marketing and Logistics, 22, 2, 135 155.

Young, Joyce A., Faye S. McIntyre, and Audesh K. Paswan (2004), “Franchisors' websites: Documenting promotional activities," Proceedings of the $18^{\text {th }}$ Conference of the International Society of Franchising.

Zachary, Miles A., Aaron F. McKenny, Jeremy C. Short, Kelly M. Davis, and Di Wu (2011), "Franchise branding: An organizational identity perspective," Journal of the Academy Marketing Science, 39, 629-645. 


\section{FIGURES}

Figure 1: Functional and symbolic dimensions in brand evaluation
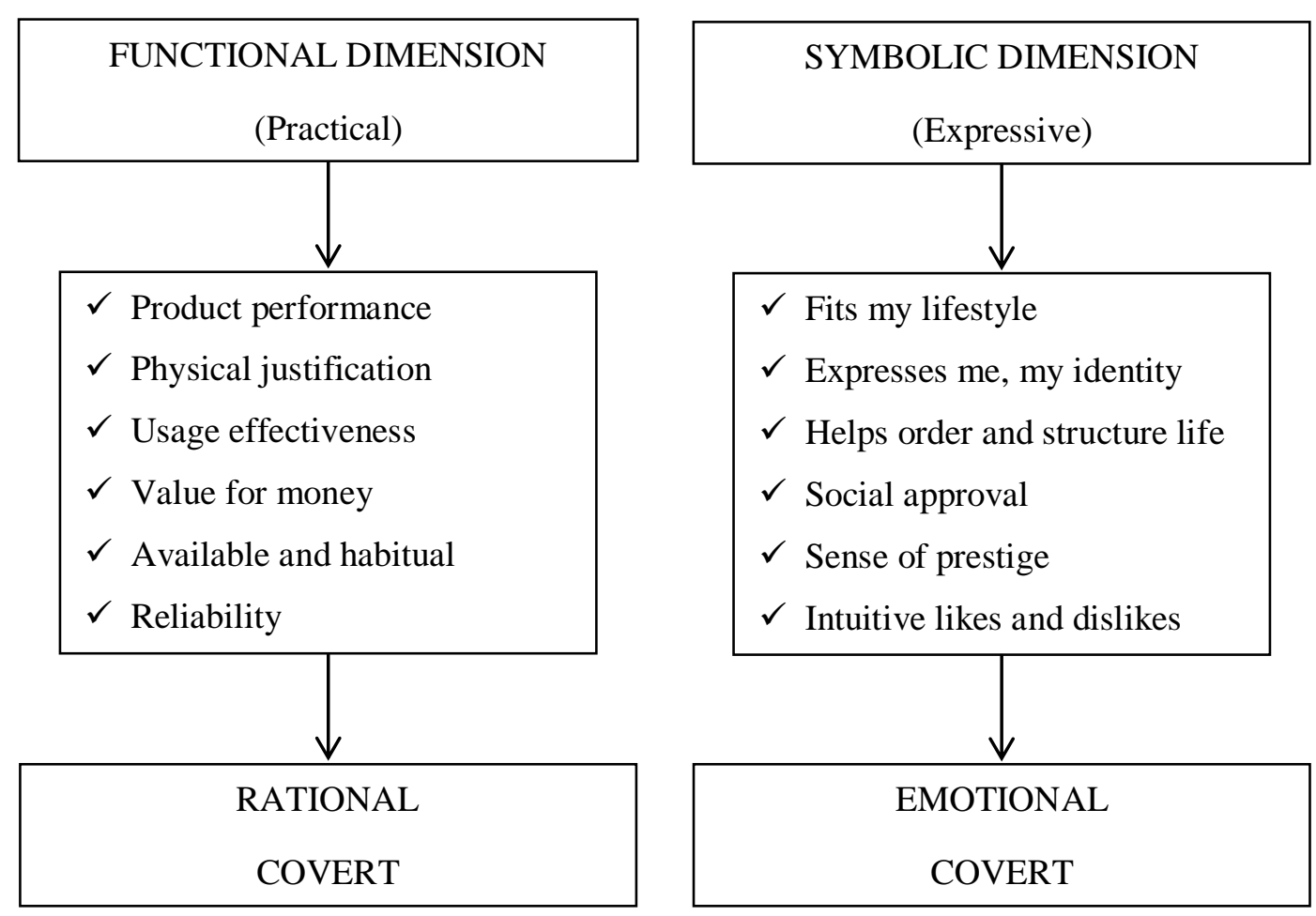

Source: del Río, Vázquez and Iglesias (2001) 


\section{TABLES}

Table 1: Description of the categories and all the associated types of information

\begin{tabular}{|c|c|}
\hline Functional benefits & $\begin{array}{l}\text { Present (Not } \\
\text { present) on } \\
\text { Franchisor } \\
\text { Website } \\
\end{array}$ \\
\hline Information on the company & $101(5)$ \\
\hline 1. Presence of the brand slogan & $59(47)$ \\
\hline 2. Presence of products/services images & $48(58)$ \\
\hline 3. Presence of stores or headquarters images & $54(52)$ \\
\hline 4. Presence of a short description of the brand & $35(71)$ \\
\hline 5. Indication of the year the company was established & $41(65)$ \\
\hline 6. Description of the brand's history & $17(89)$ \\
\hline 7. Description of the commercialized products/services & $24(82)$ \\
\hline 8. Explicit description of the concept & $62(44)$ \\
\hline 9. Description of the brand market (e.g., growth, customers) & $33(73)$ \\
\hline $\begin{array}{l}\text { 10. Indication of the affiliation with a big group or a pension } \\
\text { fund }\end{array}$ & $17(89)$ \\
\hline 11. Indication of the group's other brands & $13(93)$ \\
\hline $\begin{array}{l}\text { 12. Communication about the chain's current events (e.g., press } \\
\text { articles, press kits) }\end{array}$ & $23(83)$ \\
\hline Information on the franchise chain & $84(22)$ \\
\hline $\begin{array}{l}\text { 1. Explicit description of the know-how ("know-how" tab or } \\
\text { the word "know-how") }\end{array}$ & $22(84)$ \\
\hline 2. Presence of a definition of franchising & $35(71)$ \\
\hline 3. Mention of the year of the company was franchised & $28(78)$ \\
\hline 4. Description of the chain's history & $17(89)$ \\
\hline 5. Indication of the number of franchised stores & $55(51)$ \\
\hline 6. Indication of the number of company-owned stores & $26(80)$ \\
\hline Initial assistance & $76(30)$ \\
\hline $\begin{array}{l}\text { 1. Description of the initial training (e.g., duration, modules, } \\
\text { prices) }\end{array}$ & $56(50)$ \\
\hline 2. Indication of the existence of a Corporate University & $16(90)$ \\
\hline $\begin{array}{l}\text { 3. Presentation of the assistance provided by the franchisor to } \\
\text { the franchisee in terms of procedures with the banks }\end{array}$ & $21(85)$ \\
\hline $\begin{array}{l}\text { 4. Presentation of the assistance provided by the franchisor to } \\
\text { the franchise for the opening of the store }\end{array}$ & $44(62)$ \\
\hline Continuous assistance & $81(25)$ \\
\hline
\end{tabular}




\begin{tabular}{|c|c|}
\hline $\begin{array}{l}\text { 1. Description of the continuous training (e.g., duration, } \\
\text { modules, prices) }\end{array}$ & $31(75)$ \\
\hline 2. Mention of the role of the on-field consultant & $44(62)$ \\
\hline $\begin{array}{l}\text { 3. Presentation of the assistance provided by the franchisor to -- } \\
\text { the franchisee in terms of marketing }\end{array}$ & $34(72)$ \\
\hline $\begin{array}{l}\text { 4. Presentation of the assistance provided by the franchisor to } \\
\text { the franchisee in terms of advertisement and promotion }\end{array}$ & $47(59)$ \\
\hline $\begin{array}{l}\text { 5. Presentation of the support provided by the franchisor to the } \\
\text { franchisee in terms of purchasing (e.g., central purchasing, } \\
\text { economies of scale) }\end{array}$ & $52(54)$ \\
\hline $\begin{array}{l}\text { 6. Presentation of the assistance provided by the franchisor to } \\
\text { the franchisee in terms of sales (e.g., reservation centers) }\end{array}$ & $28(78)$ \\
\hline $\begin{array}{l}\text { 7. Presentation of the assistance provided by the franchisor to } \\
\text { the franchisee in terms of human resource management (e.g., } \\
\text { assistance with recruitment, training) }\end{array}$ & $21(85)$ \\
\hline $\begin{array}{l}\text { 8. Presentation of the assistance provided by the franchisor to } \\
\text { the franchisee in terms of computer software }\end{array}$ & $32(74)$ \\
\hline $\begin{array}{l}\text { 9. Presentation of the assistance provided by the franchisor to } \\
\text { the franchisee in terms of ICT }\end{array}$ & $19(87)$ \\
\hline $\begin{array}{l}\text { 10. Presentation of the assistance provided by the franchisor to } \\
\text { the franchisee in terms of back office (e.g., administrative, } \\
\text { judicial) }\end{array}$ & $21(85)$ \\
\hline 11. Presence of an Intranet network for franchisees & $14(92)$ \\
\hline Franchise contract & $44(62)$ \\
\hline 1. Indication of the duration of the franchise contract & $32(74)$ \\
\hline $\begin{array}{l}\text { 2. Mention of the different types of contracts used (e.g., } \\
\text { franchise, affiliation, partnership) }\end{array}$ & $11(95)$ \\
\hline 3. Description of the franchisor's and franchisee's obligations & $19(87)$ \\
\hline $\begin{array}{l}\text { 4. Presentation of the career prospects for franchisees (e.g., } \\
\text { multi-unit franchisee, pluri-franchisee) }\end{array}$ & $7(99)$ \\
\hline Financial requirements to join the chain & $61(45)$ \\
\hline 1. Indication of the amount of the entry fees & $47(59)$ \\
\hline 2. Indication of the amount of the franchising royalties & $44(62)$ \\
\hline 3. Indication of the amount of the advertising fees & $28(78)$ \\
\hline 4. Indication of other costs (e.g., training, equipment) & $14(92)$ \\
\hline $\begin{array}{l}\text { 5. Indication of the franchisee candidate's personal input } \\
\text { amount }\end{array}$ & $42(64)$ \\
\hline $\begin{array}{l}\text { 6. Indication of the amount of the total investment to open a } \\
\text { franchised store }\end{array}$ & $44(62)$ \\
\hline Business potential (financial expectations) & $40(66)$ \\
\hline $\begin{array}{l}\text { 1. Description of the benefits associated to the franchisee status } \\
\text { (e.g., capitalization) }\end{array}$ & $39(67)$ \\
\hline 2. Indication of the franchisee's potential pay & $9(97)$ \\
\hline Possibilities of contact without interaction & $36(70)$ \\
\hline $\begin{array}{l}\text { 1. Possibility for franchisee candidates to download } \\
\text { information/document resources }\end{array}$ & $20(86)$ \\
\hline 2. Presence of "Frequently Asked Questions" section & $10(96)$ \\
\hline $\begin{array}{l}\text { 3. Possibility for franchisee candidates to subscribe to a } \\
\text { newsletter }\end{array}$ & $18(88)$ \\
\hline
\end{tabular}




\begin{tabular}{|c|c|}
\hline Possibilities of contact with interaction & $105(1)$ \\
\hline $\begin{array}{l}\text { 1. Possibility for franchisee candidates to send an } \\
\text { information/documentation reauest }\end{array}$ & $32(74)$ \\
\hline $\begin{array}{l}\text { 2. Indication of the email address in the form of } \\
\text { "contact@nameofthechain" or } \\
\text { "development@nameofthechain" }\end{array}$ & $68(38)$ \\
\hline $\begin{array}{l}\text { 3. Indication of the name of the developer and his contact } \\
\text { details }\end{array}$ & $34(72)$ \\
\hline $\begin{array}{l}\text { 4. Possibility for franchisee candidates to fill in an online } \\
\text { application form }\end{array}$ & $56(50)$ \\
\hline $\begin{array}{l}\text { 5. Possibility for franchisee candidates to submit their CV } \\
\text { online }\end{array}$ & $11(95)$ \\
\hline $\begin{array}{l}\text { 6. Possibility for franchisee candidates to download an } \\
\text { application form to be sent by postal mail }\end{array}$ & $23(83)$ \\
\hline 7. Indication of a phone number & $48(58)$ \\
\hline 8. Indication of a toll free phone number & $9(97)$ \\
\hline 9. Indication of an email address & $40(66)$ \\
\hline 10. Indication of a fax number & $17(89)$ \\
\hline 11. Indication of a mailing address & $39(67)$ \\
\hline Symbolic benefits & $\begin{array}{l}\text { Present (Not } \\
\text { present) on } \\
\text { Franchisor } \\
\text { Website }\end{array}$ \\
\hline Aesthetic aspects of the website & $89(17)$ \\
\hline 1. Presence of images/photos of people & $57(49)$ \\
\hline 2. Presence of videos & $31(75)$ \\
\hline $\begin{array}{l}\text { 3. Animation of graphs, images or links (e.g., new pop-up } \\
\text { windows opening) }\end{array}$ & $53(53)$ \\
\hline 4. Use of colors for background & $18(88)$ \\
\hline 5. Use of colors for text font & $33(73)$ \\
\hline Corporate strategy and leadership & $61(45)$ \\
\hline 1. Mission & $16(90)$ \\
\hline 2. Vision & $41(65)$ \\
\hline 3. Culture & $19(87)$ \\
\hline 4. CEO bio & $23(83)$ \\
\hline Activities dealing with Corporate Social Responsibility & $38(68)$ \\
\hline $\begin{array}{l}\text { 1. Presence of images of people whatever their gender, age or } \\
\text { background }\end{array}$ & $34(72)$ \\
\hline $\begin{array}{l}\text { 2. Presence of information regarding the CSR practices of the } \\
\text { franchisor }\end{array}$ & 7 (99) \\
\hline Activities dealing with social media & $42(64)$ \\
\hline 1. Possibility of sharing 'my Internet' page with a friend & $9(97)$ \\
\hline 2. Presence of a link to the Facebook page & $38(68)$ \\
\hline 3. Presence of a link to the Twitter account & $15(91)$ \\
\hline Certifications & $33(73)$ \\
\hline 1. Presence of label logos (e.g., ISO, product of the year) & $8(98)$ \\
\hline 2. Indication of awards/prizes received by the franchisor & $14(92)$ \\
\hline 3. Presence of the French Franchise Federation logo & $21(85)$ \\
\hline Personality traits & $73(33)$ \\
\hline
\end{tabular}




\begin{tabular}{|l|l|}
\hline 1. Explicit mention as "Be successful!", "Get started!" & $22(84)$ \\
2. Mention of a franchise specific slogan (e.g., "Is franchising & $28(78)$ \\
right for you?") & $58(48)$ \\
\hline Human aspects & $66(40)$ \\
\hline 1. Mention of success stories & $19(87)$ \\
2. Presence of the "message" from the franchisor & $14(92)$ \\
3. Indication of the latest openings & $28(78)$ \\
4. Presence of accounts from franchisees in written form & $29(77)$ \\
5. Presence of accounts from franchisees in video form & $14(92)$ \\
6. Indication of the brand's attendance at the franchise & $12(94)$ \\
7. Indication of the name of the franchisees and their contact & $9(97)$ \\
\hline details & $\mathbf{6 9}(\mathbf{3 7})$ \\
\hline Recruitment process of franchisee candidates & $15(91)$ \\
\hline 1. Indication of the areas (e.g., cities) for which a franchisee is & $1(105)$ \\
2. Preeded & $13(93)$ \\
\hline 3. Description of the selection process of franchisee candidates & $60(46)$ \\
\hline Working environment (premises and employees) & $48(58)$ \\
\hline $\begin{array}{l}\text { 1. Indication of the necessity of having premises } \\
\text { 2. Indication of the size of the store }\end{array}$ & $38(68)$ \\
3. Indication of the type and quality of the location (e.g., No. 1, & $39(67)$ \\
town center, showcase, car park) & $14(92)$ \\
4. Indication of the average number of employees required for \\
$\begin{array}{l}\text { the business } \\
\text { (e.g., duration, modules, pricing) }\end{array}$
\end{tabular}


Table 2: Descriptive statistics for the categories of information

\begin{tabular}{|lccccc|}
\hline & $\mathbf{N}$ & Minimum & Maximum & Mean & Standard deviation \\
\hline Functional benefits & & & & & \\
\hline Information on the company & 106 & 0 & 0.83 & 0.3349 & 0.20019 \\
Information on the franchise chain & 106 & 0 & 1 & 0.2877 & 0.24509 \\
Initial assistance & 106 & 0 & 1 & 0.3231 & 0.26941 \\
Continuous assistance & 106 & 0 & 0.82 & 0.2942 & 0.22707 \\
Franchise contract & 106 & 0 & 1 & 0.1627 & 0.22372 \\
Financial requirements to join the chain & 106 & 0 & 1 & 0.3443 & 0.34905 \\
Business potential (financial expectations) & 106 & 0 & 1 & 0.2264 & 0.31722 \\
Possibilities of contact without interaction & 106 & 0 & 1 & 0.1509 & 0.23963 \\
Possibilities of contact with interaction & 106 & 0 & 0.73 & 0.3233 & 0.13518 \\
\hline Symbolic benefits & 106 & & & & \\
\hline Aesthetic aspects of the website & 106 & 0 & 1 & 0.3623 & 0.24860 \\
Corporate strategy and leadership & 106 & 0 & 1 & 0.2335 & 0.24945 \\
Activities dealing with Corporate Social Responsibility & 106 & 0 & 1 & 0.1934 & 0.27230 \\
Activities dealing with social media & 106 & 0 & 1 & 0.1950 & 0.27165 \\
Certifications & 106 & 0 & 1 & 0.1352 & 0.21956 \\
Personality traits & 106 & 0 & 1 & 0.3396 & 0.29089 \\
Human aspects & 106 & 0 & 0.71 & 0.1685 & 0.17832 \\
Recruitment process of franchisee candidates & 106 & 0 & 1 & 0.2799 & 0.25255 \\
Working environment (premises and employees) & 106 & 0 & 1 & 0.3038 & 0.32453 \\
\hline
\end{tabular}


Table 3: Descriptive statistics for the chain characteristics

\begin{tabular}{|lccccc|}
\hline Chain characteristics & N & Minimum & Maximum & Mean & Standard deviation \\
\hline Chain age & 106 & 1 & 62 & 11.25 & 10.55 \\
Chain size & 94 & 3 & 507 & 111.29 & 126.82 \\
Percentage of company-owned stores & 94 & 0 & 94.30 & 28.36 & 26.15 \\
Industry & 106 & 0 & 1 & 0.67 & 0.473 \\
International dimension & 104 & 0 & 1 & 0.43 & 0.498 \\
\hline
\end{tabular}


$\underline{\text { Table 4: Estimation results of the linear regression model }}$

\begin{tabular}{|c|c|c|c|}
\hline & \multicolumn{3}{|c|}{ Franchise chain growth } \\
\hline & Model 0 & Model 1 & Model 2 \\
\hline (Constant) & $\begin{array}{c}10.053^{* *} \\
(4.298)\end{array}$ & $\begin{array}{c}7.941 \\
(6.975) \\
\end{array}$ & $\begin{array}{c}4.576 \\
(7.198) \\
\end{array}$ \\
\hline \multicolumn{4}{|l|}{ Functional benefits } \\
\hline Information on the company & & $\begin{array}{c}-4.104 \\
(13.374)\end{array}$ & $\begin{array}{c}-9.044 \\
(13.760)\end{array}$ \\
\hline Information on the franchise chain & & $\begin{array}{c}10.829 \\
(10.212)\end{array}$ & $\begin{array}{l}10.801 \\
(9.987)\end{array}$ \\
\hline Initial assistance (centered) & & $\begin{array}{l}-7.813 \\
(7.138)\end{array}$ & $\begin{array}{c}-3.862 \\
(15.473)\end{array}$ \\
\hline Initial assistance*Industry & & & $\begin{array}{c}-3.541 \\
(17.925)\end{array}$ \\
\hline Continuous assistance (centered) & & $\begin{array}{c}0.983 \\
(9.588)\end{array}$ & $\begin{array}{l}-24.441 \\
(15.914)\end{array}$ \\
\hline Continuous assistance*Industry & & & $\begin{array}{l}32.687^{*} \\
(18.908)\end{array}$ \\
\hline Franchise contract & & $\begin{array}{l}-12.915 \\
(9.437)\end{array}$ & $\begin{array}{l}-9.360 \\
(9.543)\end{array}$ \\
\hline $\begin{array}{l}\text { Financial requirements to join the } \\
\text { chain }\end{array}$ & & $\begin{array}{c}16.617 * * \\
(6.566)\end{array}$ & $\begin{array}{c}17.700 * * \\
(6.548)\end{array}$ \\
\hline Business potential (financial & & $-14.542 * *$ & $-18.775^{*}$ \\
\hline expectations) (centered) & & $(6.007)$ & $(11.075)$ \\
\hline $\begin{array}{l}\text { Business potential (financial } \\
\text { expectations) *Industry }\end{array}$ & & & $\begin{array}{c}4.769 \\
(13.482)\end{array}$ \\
\hline Possibilities of contact without & & $15.790 * *$ & $13.447 *$ \\
\hline interaction & & $(7.834)$ & $(8.084)$ \\
\hline Possibilities of contact with & & -23.700 & -18.780 \\
\hline interaction & & $(15.624)$ & $(15.497)$ \\
\hline \multicolumn{4}{|l|}{ Symbolic benefits } \\
\hline Aesthetic aspects of the website & & $\begin{array}{l}-12.920 \\
(8.630)\end{array}$ & $\begin{array}{l}-11.224 \\
(8.617)\end{array}$ \\
\hline Corporate strategy and leadership & & $\begin{array}{l}-8.288 \\
(9.270)\end{array}$ & $\begin{array}{l}-7.840 \\
(9.067)\end{array}$ \\
\hline Activities dealing with Corporate & & 0.586 & -1.717 \\
\hline Social Responsibility & & $(7.715)$ & $(7.725)$ \\
\hline Activities dealing with social media & & $\begin{array}{c}3.792 \\
(6.999)\end{array}$ & $\begin{array}{c}4.017 \\
(6.923)\end{array}$ \\
\hline Certifications (centered) & & $\begin{array}{c}15.049 \\
(10.207)\end{array}$ & $\begin{array}{c}-7.478 \\
(21.209)\end{array}$ \\
\hline Certifications *Industry & & & $\begin{array}{c}29.920 \\
(22.390)\end{array}$ \\
\hline Personality traits & & $\begin{array}{c}5.955 \\
(6.669)\end{array}$ & $\begin{array}{c}7.087 \\
(6.689)\end{array}$ \\
\hline
\end{tabular}




\begin{tabular}{|lccc|} 
Human aspects & & 13.515 & 11.733 \\
Recruitment process of franchisee & & $(14.192)$ & $(14.107)$ \\
candidates & & $(7.597)$ & $26.503 * * *$ \\
Working environment (premises and & & -1.353 & $(7.978)$ \\
employees) & & $(7.349)$ & 0.370 \\
\hline Chain characteristics & & & $(7.526)$ \\
\hline Chain age & -0.228 & -0.310 & -0.315 \\
& $(0.192)$ & $(0.193)$ & $(0.196)$ \\
Chain size & $0.078^{* * *}$ & $0.067 * * *$ & $0.073^{* * *}$ \\
Percentage of company-owned & $(0.016)$ & $(0.018)$ & $(0.18)$ \\
stores & $-0.180^{* *}$ & $-0.215^{* * *}$ & $-0.246 * * *$ \\
Industry & $(0.069)$ & $(0.072)$ & $(0.074)$ \\
& 2.830 & -0.038 & 1.648 \\
International dimension & $(3.708)$ & $(4.176)$ & $(4.214)$ \\
N & -3.107 & 0.990 & 1.646 \\
F & $(4.156)$ & $(4.393)$ & $(4.559)$ \\
$\mathrm{R}^{2}$ (adjusted) & 91 & 91 & 91 \\
\hline
\end{tabular}

Significance levels are noted: $* * * \mathrm{p}<1 \%$; $* * \mathrm{p}<5 \%$; $* \mathrm{p}<10 \%$.

Standard errors are in parentheses 